\title{
Bosnian Cardaklia House: The Osmic Family's House in Mala Brijesnica near Gračanica
}

\author{
Ahmet Hadrović ${ }^{*}$ \\ Faculty of Architecture, University of Sarajevo, Sarajevo, Bosnia and Hercegovina
}

Citation: Hadrović A. Bosnian Cardaklia House: The Osmic Family's House in Mala Brijesnica near Gračanica. SEE J Archit Des. Sep 13, 10050:1-7. ittp://dx.doi.org/10.3889/seejad.2020.10050 Keywords: Osmic family; Mala Brijesnica; Chardaclia; Bioclimatic architecture

Correspondence: Prof. Dr. Ahmet Hadrović, Faculty of Architecture, University of Sarajevo, Sarajevo, Bosnia and Hercegovina. E-mail: ahmeth@af.unsa.ba

Received: 03-Sep-2020; Revised: 07-Sep-2020; Accepted: 8-Sep-2020; Published: 13-Sep-2020

Copyright: ๑ 2020 Ahmet Hadrović. This is an open-access Ander the terms of the Creative Commons Attribution License, which permits unrestricted use, distribution, and reproduction in any medium, provided the original author and source are credited.

Competing Interests: The author have declared that no competing inter

\section{Abstract}

The Osmic family's house in Mala Brijesnica near Gracanica is located on flat terrain, on a slope with southwestern exposure. The house was built by Mr. Redzo Osmic in 1920-1926 years. The house is one of the most preserved examples of the authentic bosnian chardaklia house in Gracanica, but also in Bosnia and Herzegovina as a whole.

The Osmic family's house in Mala Brijesnica near Gracanica, according to the disposition of their horizontal plans, belongs to the type of three-tracs bosnian chardaklia house, which was developed through the basement ground floor and first floor in a vertical slab.

The dispositions of the horizontal plans of the house are designed in such a way that the house can be divided both horizontally and vertically into more autonomous housing units, which is one of the specifics of the Bosnian chardaklia house. According to its spatial concept, construction, and materialization, and securing the cryptoclimate of space, the Osmic family house is an example of traditional bioclimatic architecture in Bosnia and Herzegovina.

\section{Introduction}

The archetype from which the bosnian chardaklia house evolved is the traditional solution of the bosnian house, which can still be seen in preserved houses on the mountains of Bosnia and Herzegovina, whether in permanently populated villages or temporary settlements-katuns (Figure 1 and Figure 2, left and center).

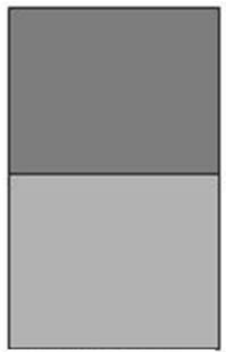

BASEMENT
GROUND FLOOR

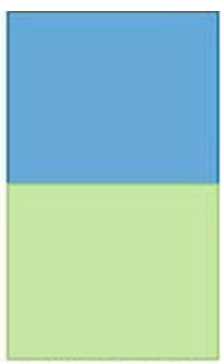

Figure 1: The starting point (archetype) of the Bosnian chardaklia house

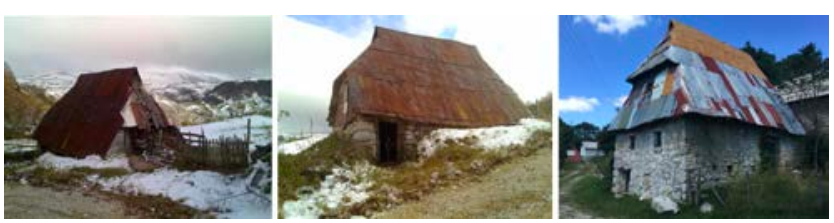

Figure 2: Left and center - House in the Umoljani village on the Bjelasnica plateau (Gradina); Right - House in the Cuhovici village near Konjic. The appearance of the floor (the "chardak between the horns" - "čardak među rogovima")

This house, in principle, has a ground floor developed through two tracts, with one tract on the ground (the "house" - "kuća") and the other above the basement. Most of these houses were built on hilly terrain, which was ideal for developing the (desired) plan in the vertical, basement and ground floor. The basement is arranged just below one ground floor tract. The bosnian chardaklia house has a characteristic volume of roof that is a kind of especially shaped fourstorey roof (Figure 2, right). 
The economic strength of the family, always accompanied by the greater number of its members, also required a larger area of the house. This demand led to the development of a horizontal and vertical plan of the bosnian house-archetype. Development in the horizontal plan is reflected in the addition of another, third, tract in the basics, while the development in the vertical plan is reflected in the addition of one or two floors above the ground floor (Figure 3).

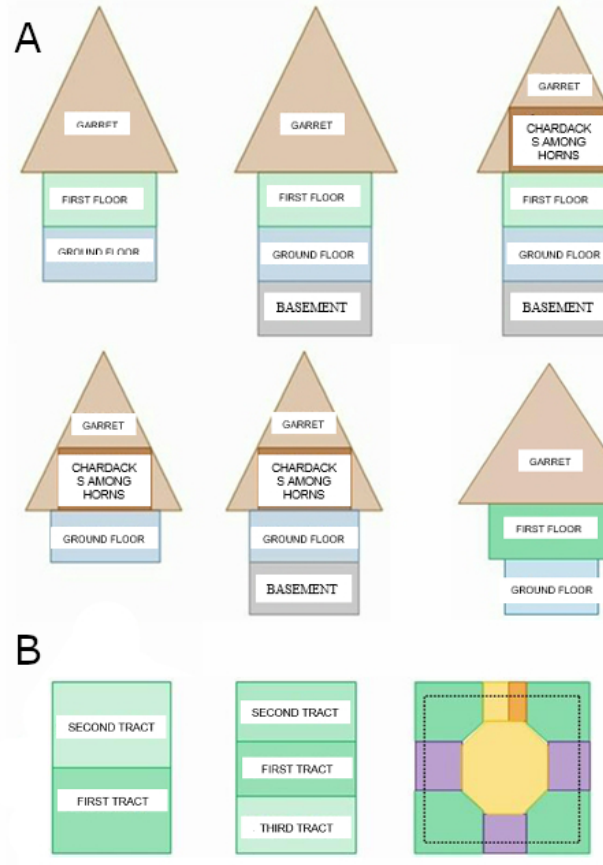

Figure 3: A) Basic schematic diagrams of the bosnian chardaklia house vertical plan; B) Basic schematics of the horizontal layout of the bosnian chardaklia house

Considering the spatial and shape characteristics of the bosnian chardaklia house throughout Bosnia and Herzegovina, there are three basic types:
a) Two-tracts (2 Tr),
b) Three-tracts houses ( $3 \mathrm{Tr}$ ),
c) Central House Solution (CHS), (Figure 3).

In this case, two-tracs, three-tracs and central solution houses, in their vertical plan, can be developed through the scheme:

a) Ground floor plus first floor (PrK),

b) Basement plus ground floor plus first floor (SPrK), and c) Basement plus ground floor plus first floor plus garret (SprKPo), (Figure 3).

Each of these types, locally or regionally, may have additional specifics such as: precise symmetry in the vertical plane of symmetry, asymmetry, doxate ejection of floors (one or two sides), doxate ejections of the entire floor.

\section{Spatial and Design Characteristics of the Osmic Family's House in Mala Brijesnica near Gracanica}

The Osmic family's house in Mala Brijesnica near Gracanica, according to the layout of their horizontal plans, belongs to the type of three-tracs Bosnian chardaklia house, which was developed vertically through the basement, ground floor and first floor (Figure 4 and Figure 5).
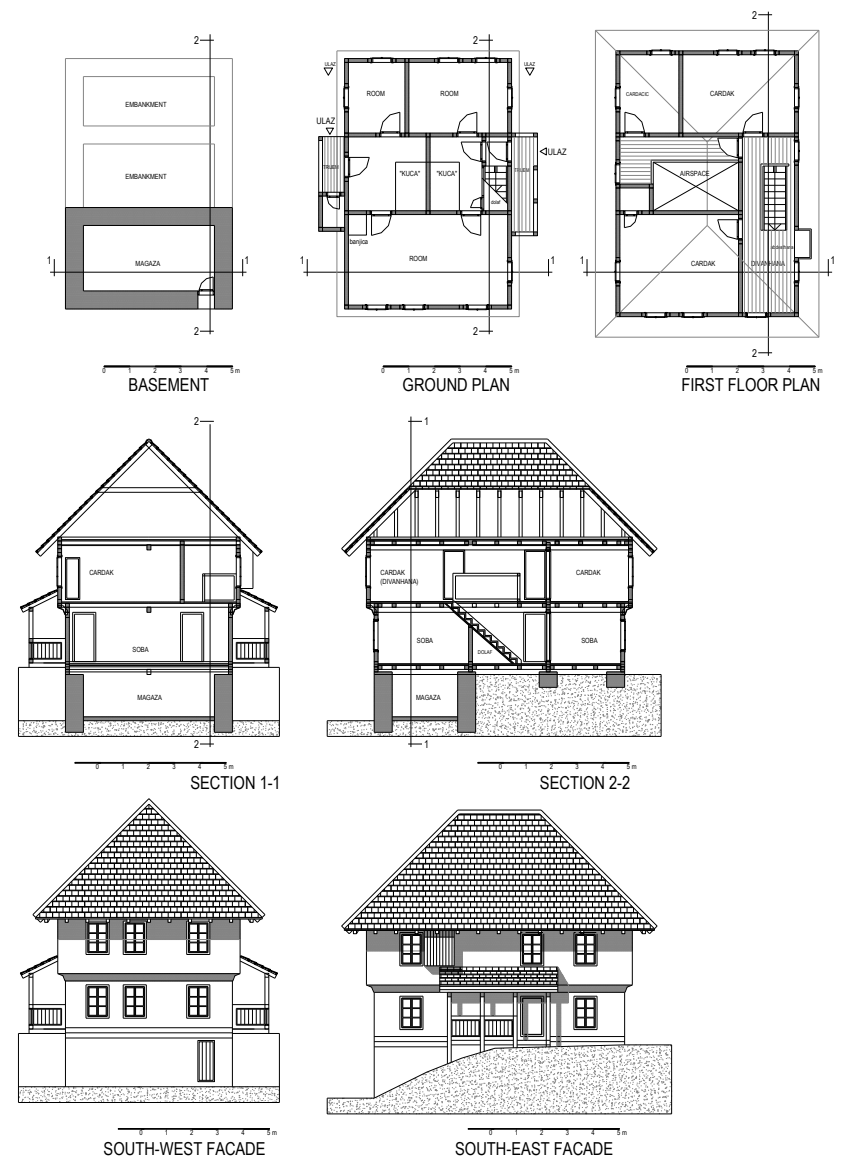

Figure 4: Osmic family house in Mala Brijesnica near Gracanica, (Disposition)

According to the layout and overall architectural physiognomy, the house has many similarities to the famous Mara Popovic's house in Gracanica. The basement of the house (home pantry, storeroom) is done just below one tract of the ground floor. The dispositions of the horizontal plans of the house are designed in such a way that the house can be divided both horizontally and vertically into more autonomous housing units.

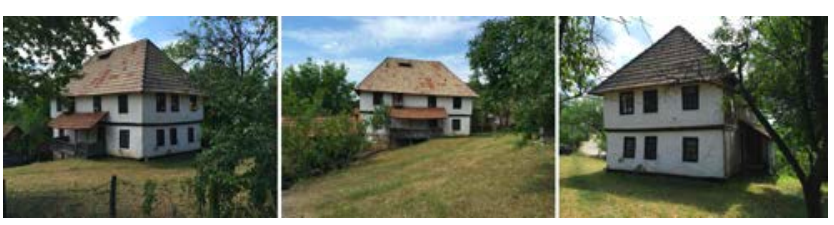

Figure 5: Osmic family house in Mala Brijesnica near Gracanica 
The basement of the house is developed just below one tract of its ground floor basement. Functionally, the basement (here called the storeroom - "magaza") is the main pantry where food is stored for a long period of time (potatoes, fresh fruits, cables with cheese, honey...). Because it is largely buried in the ground, with thick stone walls, the basement has stable temperatures, both in summer and winter (Figure 4. and 6).
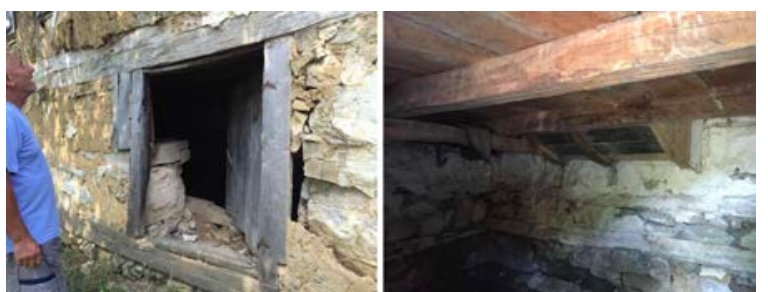

Figure 6. Left - entrance to the storeroom ("magaza"); Right basement area. Below the ceiling, in the corner, you can see a special structure with a thick layer of slag that has been made under the brick oven in the room. It was a fire protection of the wooden elements of the floor basement-ground floor structures

House on the ground floor has two entrances, one on the southeast and the other on the northwest side of the house. In front of the entrances there are porches with wooden columns and a fence, in the scale of a man (Figure 7).

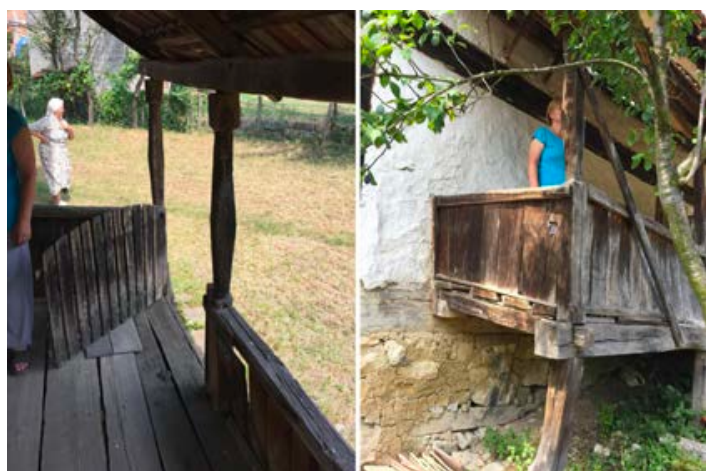

Figure 7: Porch on the southeast side of the house

The entrances are arranged in the middle ground floor tract. From the entrance porch, a narrow space with a single wooden staircase ("basamaci") leading to the first floor is first accessed. Seen from the outside, there is no detail to suggest the existence of a staircase at that location (Figure 8 and 9).

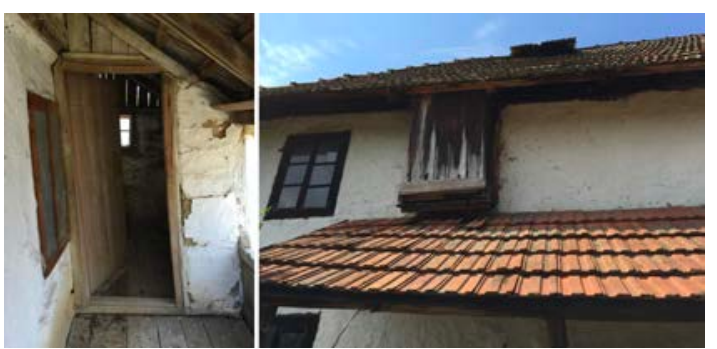

Figure 8: Left - $A$ handy pantry next to the entrance porch on the northwest side of the house; Right - Abdestana (niche for ritual washing) upstairs (above the entrance porch on the southeast side of the house)

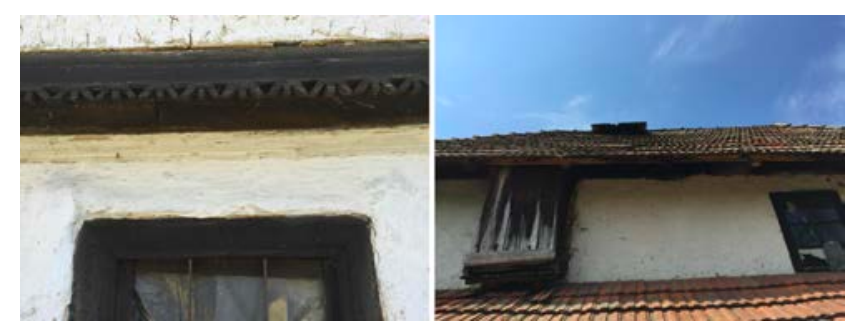

Figure 9: Left - Ground floor cantilever transition is further emphasized by a decorative, profiled plank; Right - Smoke vent (badge) from the garret space to the open space

The central tract of the house is an open space, from the ground floor to the roof. It could be said (also from the perspective of modern understanding of the term "bioclimatic architecture") that this space is the "heart" of the spatial-functional concept of the house and its functioning as a bioclimatic building (Figure 10 and Figure 11).

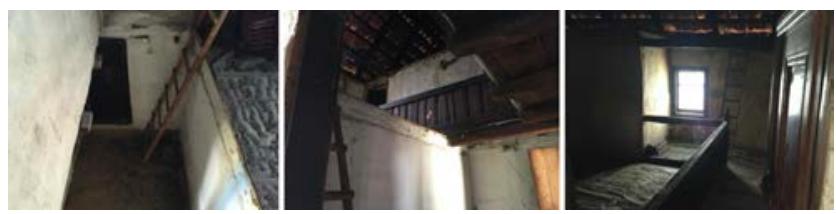

Figure 10: Left and center - Gallery view of "home" ("kuća") spaces, Right - Gallery with ladders to get out into the roof space

On the ground floor level of the central tract of the house is a living room with an open hearth. The living room has the name "house" ("kuća"), and given its central location, it was a gathering place for families and central communication from which all other rooms of the house were accessed. The smoke from the open hearth rose into the open space, through the floor level to the roof space. Smoke played a key role in ensuring that all wooden elements of the house (especially the roof structure, shingles and wooden doors and windows) are protected from the aggressive action of insects and moisture. The tar from the smoke permanently impregnated the tree, giving it a specific hint of honey over time (Figure 10).
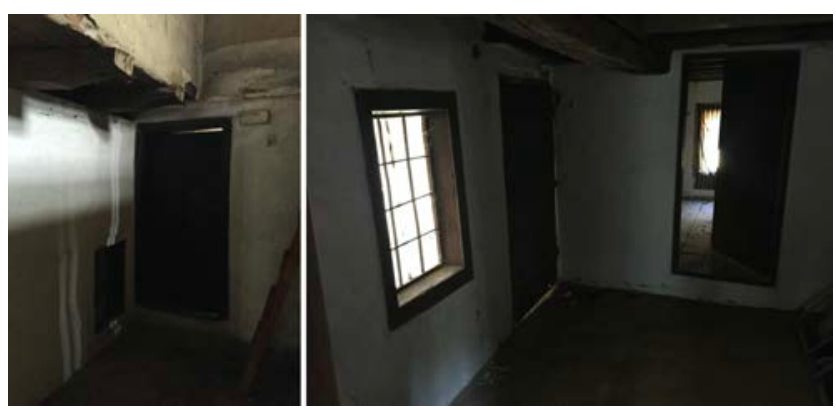

Figure 11: Left - Detail of the "house" ("kuća") space (in the southeast part of the building) on the ground floor with the front door of the room; Right - The "house" ("kuća") space in the northwestern part of the property overlooks the front door and toward the small room

From the premises of the "house", on the ground floor level, it is accessed into three rooms, one 
of which is the "large room", with the most favorable orientation, which extends over the entire far tract of the base of the house (Figures 4, 12 and 13). In the other far tract are two rooms.
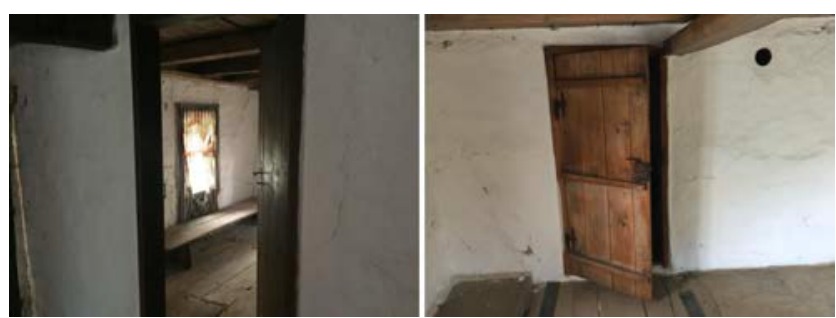

Figure 12: Left - View from the "house" ("kuća") space through an open door in a small room; Right - entrance to the "big room"

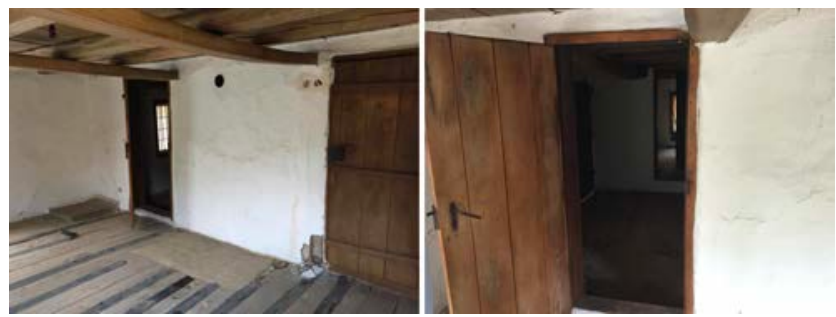

Figure 13: Left - "Big room" on the ground floor, above the basement; Right - View from the "big room" through the open door to the space of the "house" ("kuća") and towards the room in the third tract

The single-storey staircase from the ground floor (Figure 14) first enters the divanhana space upstairs. At the floor level there are three chardaks, one large (above the big room on the ground floor) and two small chardaks (above the rooms on the ground floor).

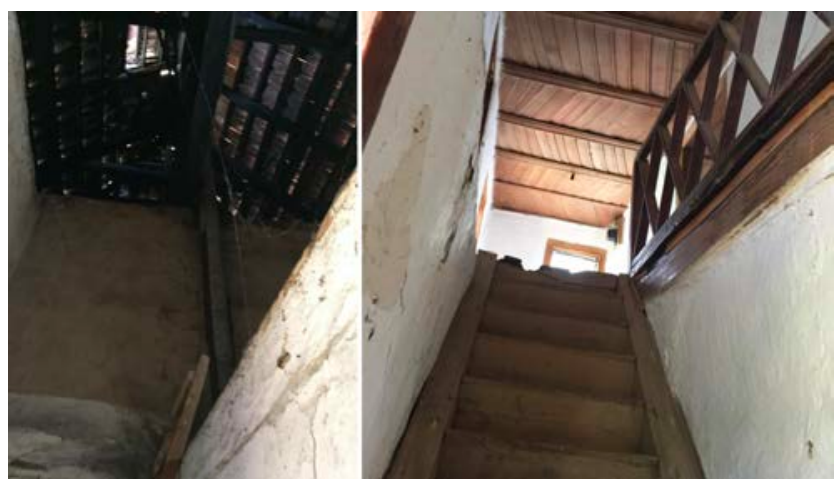

Figure 14: Left - View from the "house" ("kuća") space towards the garret and roof; Right - View from entrant windshield to staircase to floor and divanhana

From the divanhana space it is accessed in two chardaks and on the gallery, which is on the ground floor-first floor level, at the edge of the middle tract, above the space of the "house" ("kuća") on the ground floor (Figure 15 and 16).

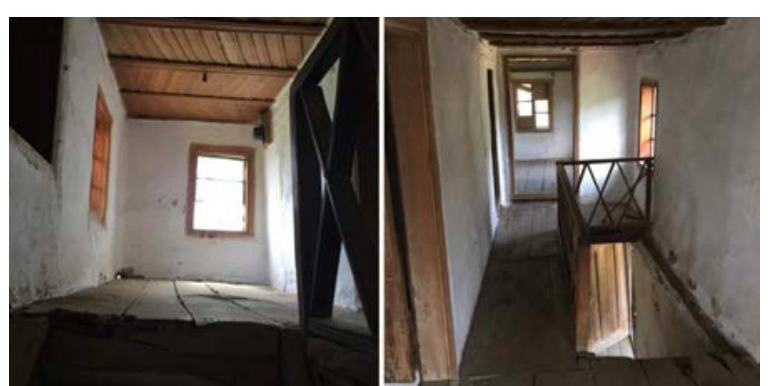

Figure 15: Left - View of divanhana space from staircase; Right View from the divanhana to the staircase and to the front door to the chardak and gallery above the "house" ("kuća")

This gallery is accessed on the opposite side of the house where, in the wall between the middle and one of the two end tracts, there is an entrance door for the third chardak.
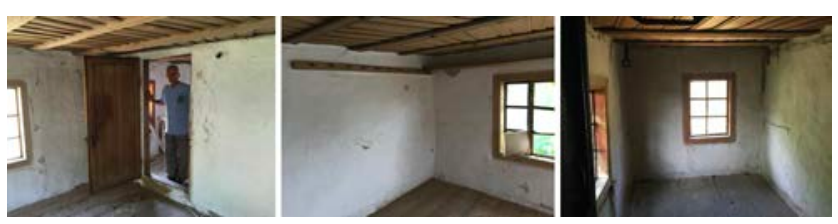

Figure 16: Left and center - Small chardak with entrance from divanhana space; Right - A small chardak with a gallery entrance

Floor-level gallery is one of the most beautiful architectural solutions in this house, which is a sign of a high understanding of the value of space and its functional and aesthetic design (Figure 17, left).

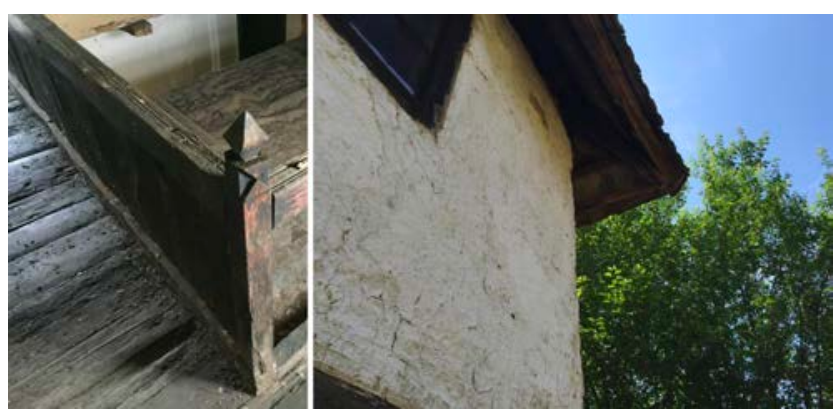

Figure 17: Left - Detail of fence on gallery; Right - Finishing of exterior wall surfaces: white painted clay mortar with straw and chaff

The basement contours are projected into the space by about $30 \mathrm{~cm}$ on all sides of the ground floor contour. This floor emphasis is common in northern and northeastern Bosnia and the Bosnian krajina. This solution has a number of advantages: it increases the usable floor area in relation to the usable floor area, the protruding floor protects the walls and openings of the ground floor from the harmful effects of the weather, the floor console has a shadow effect on part of the ground floor height... 
There are deep aesthetic reasons for the space outside the ground floor contour, since it is suggested to the observer from the outside that the "house is rich", that the house is a "white tower" (Figure $5)$.

The roof of the house is a four-sides, mediumslope, with tile cover (which replaced the original shingle cover).

\section{Construction and Materialization}

In the construction and materialization of the Osmic family's house in Mala Brijesnica near Gracanica, natural materials were used, in places and in a way that best corresponds with the properties of the materials.

The basement walls are made of stone (about $70 \mathrm{~cm}$ thick) with the use of loam mortar with the addition of chaff (Figure 18). The walls of the ground floor and the first floor are made in a wooden bondruck system filled with elements made of clay with the addition of straw and chaff (named "ćerpič"), sun-dried, known as "bricks". The thickness of these walls is about $14-15 \mathrm{~cm}$ (Figure 18, right).

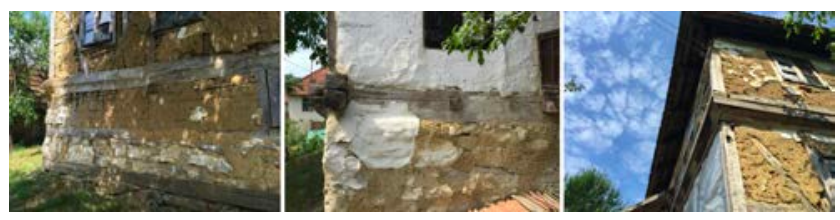

Figure 18: Details of the structural assembly of the house; Left and center - Basement wall of semi-finished stone; Right - Bondruk system with adobe fill (ground floor and first floor)

The roof structure is made of wood, and the (original) roof cover is made of wooden boardsshingles. Over time, the shingle cover was replaced by a pressed ceramic tile cover (Figure 19).
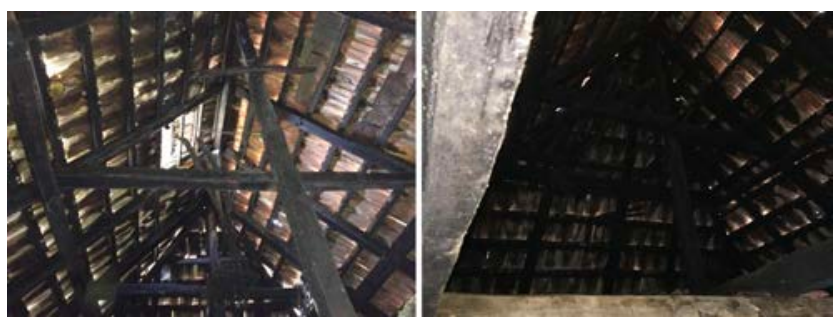

Figure 19: Roof construction (see wooden grate-shelf for drying cheese)

The ceiling structure is made of wooden beams at a distance of about $80 \mathrm{~cm}$, where the floor is made of thick wooden boards (5-7 cm tick). At a certain height of the ceiling beams, the ceiling was made of finely treated wooden boards ("šiše"), while the space between the floor and the ceiling was filled with clay charge with the addition of straw and chaff, which had the function of acoustic insulation (Figure 20).

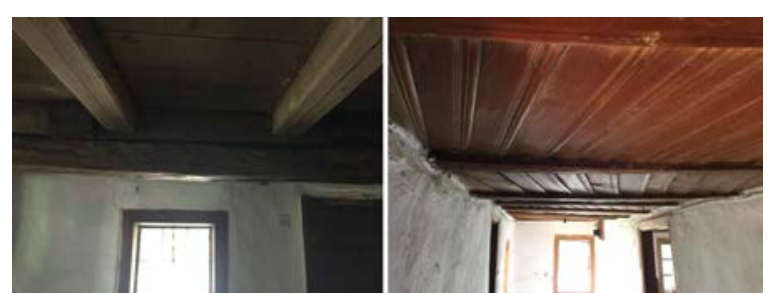

Figure 20: Left - Ground floor-first floor structure above one part of the "house" ("kuća") space; Right - Wooden ceiling ("šiše") in divanhana space

Ceiling boards were placed perpendicular to the beams or "fish bone" style, which was a more representative solution (Figure 21).

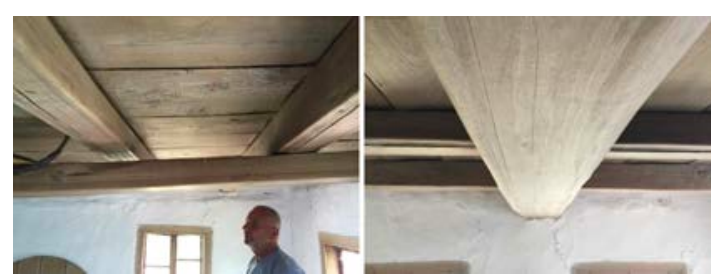

Figure 21: Wooden ceiling in a large chardak

\section{Doors and Windows}

Both doors and windows are made of wood, in the best tradition of the traditional architecture of this part of Bosnia and Herzegovina. Some doors are rustic (Figure 22) and some are examples of top-notch traditional architecture.

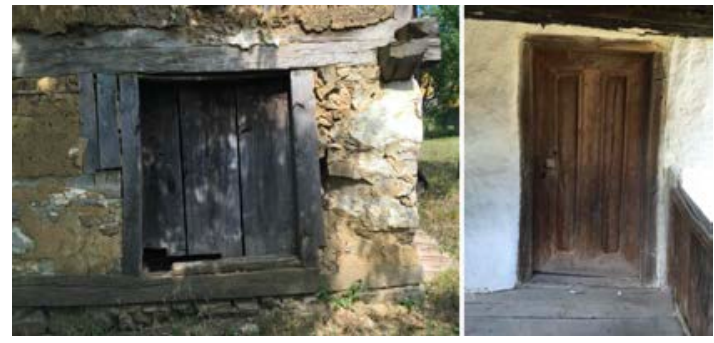

Figure 22: Left - Door on the basement wall; Right - Entrance door to the house (from the porch on the southeast side of the house)

The level of artistic door-making, as well as the wood used to make them, corresponds to the representativeness of the space on which they are set (Figures 23, 24 and 25).

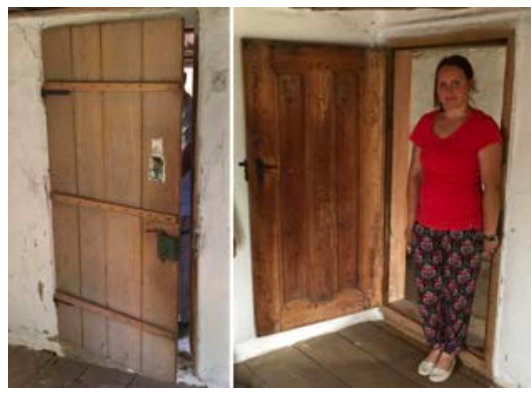

Figure 23: Left - Door at the entrance to a small chardak (divanhana oriented); Right - Door at the entrance to the room 


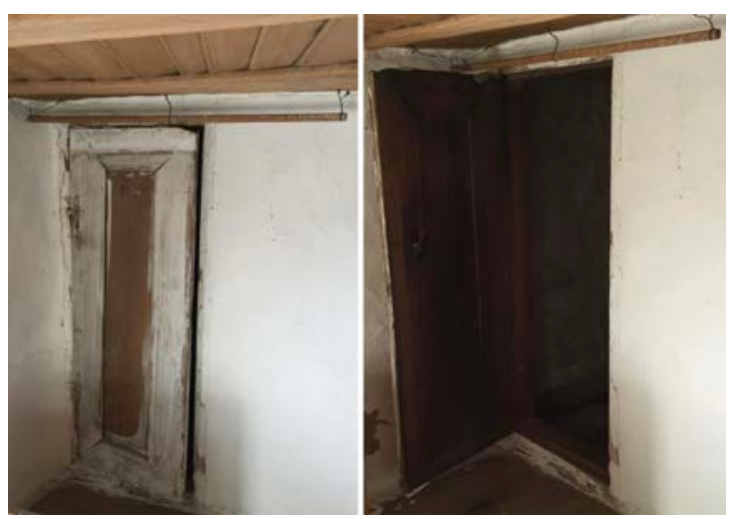

Figure 24: "Treasure door" in a large chardak

The windows are of relatively small dimensions of rectangles, single with single glazing. The windows are flush with the exterior surfaces of the walls and their profile is lined with wooden boards (Figure 5).
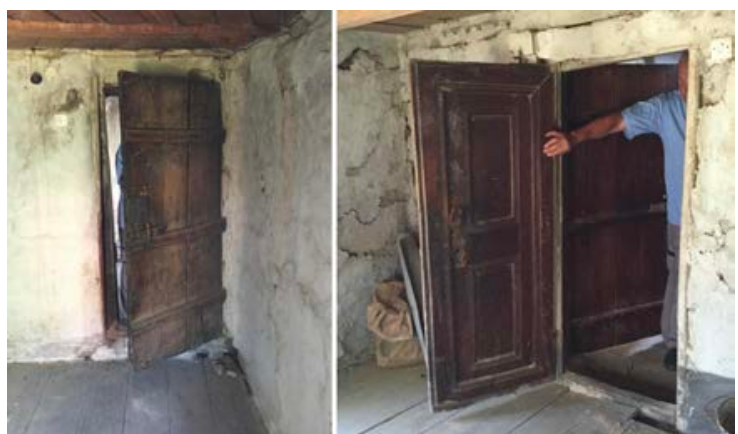

Figure 25: Left - Door on a small gallery (gallery oriented); Right Small room door and door at entrance to "house" ("kuća") space from narrow hallway with staircase (in the background)

Window frames ("window boxes") follow the thickness of the walls. The windows on the sash windows were shredded, making the window appear larger than its actual size, and the window panes were safer than their eventual breakage. The house is mostly preserved original elements of openings that are almost 100 years old (Figure 26).
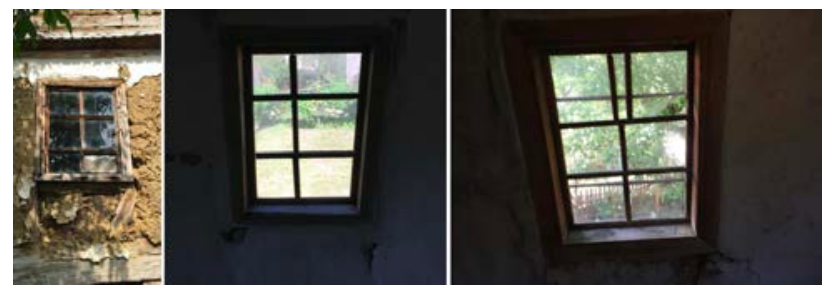

Figure 26: Left - Original window in ground floor wall; Middle - Views out the window in a large chardak; Right - Views out the window in a small chardak

\section{Surface Treatment}

The stone walls are basement in "natural" design, not plastered (Figure 18). Both the exterior and interior wall surfaces of the ground and first floors are plastered with clay mortar with the addition of (in small quantities) sand and straw and chaff. These additives improved the properties of the mortar in a way that prevented it from cracking due to temperature dilations and made it porous, which made it permeable to water vapor, that is, allowing it to breathe space. The flooring in the rooms (ground floor) and chardak (first floor) is made of thicker wooden "floors" ("podnice"), while the floor in the living room area - "kuća" (ground floor) is made of compacted earth with the addition of horsehair, as an "reinforcement bar" (Figure 27, right). The basement floor is of compacted earth.

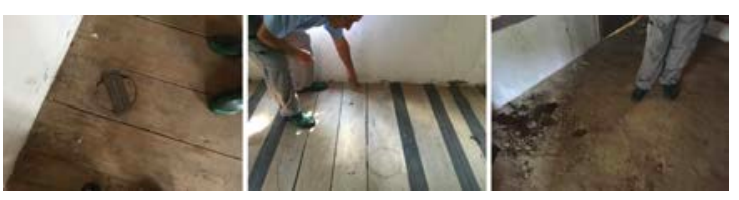

Figure 27: Left - A lid in the floor through which hot air was introduced from the ground floor room where the furnace was burning; Middle The opening in the floor from where the cable went to the front door to the house - the "remote control" system; Right - Ground floor in the "house" ("kuća") area

The Present Condition and Purpose of the House (Perspectives)

The physical structure of the Osmic family's house in Mala Brijesnica near Gracanica is well preserved, with the preservation of the roof structure and cover being particularly important. The facility is not actively used but is carefully monitored and maintained. Given the nearly 100-year-old age of the facility, there are a large number of participating heirs. What is important at the moment is the awareness of these people about the value of this building (During his visit to this house (07/09/2016.) the author, after socializing with Mr. Hajrudin Osmic, one of the coowners of this facility, remained convinced that this facility was professionally and qualitatively restored in those elements of its physical structure that were devastated. In addition, the author remained convinced that they were closest) (Figures 5, 16, 20, and 28).

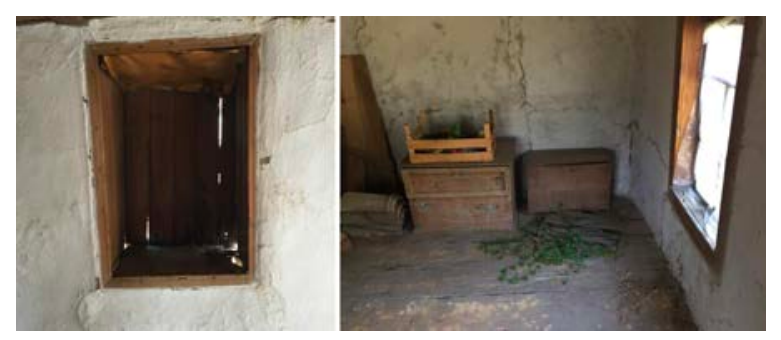

Figure 28: Left - View of a niche for ritual washing (abdesthanu) from divanhana; Right - Small room (oriented to the "house" ("kuća")). It also served as a pantry ("huđera")

\section{Bioclimatic Principles of Construction}

The Osmic family's house in Mala Brijesnica near Gracanica is an example of traditional bioclimatic 
architecture of Bosnia and Herzegovina. The principles of bioclimatic architecture are reflected in the following:

1. The building is located on a slope terrain with southern exposure,

2. The basement is partly buried in the terrain, ensuring its storage function with a constant temperature (during all seasons),

3. In all elements of construction, natural materials used were taken on site, with a place in the building that corresponds to their best features,

4. Disposition of the building (horizontal and vertical plan) ensures the function of a central space with an open hearth as a space that provides natural ventilation of the object (good cryptoclimate) and protection of all elements of the object made of wood against the aggressive action of insects and moisture,

5. The heating of individual rooms and chardakas is ensured by masonry stoves, using wood as firewood, whereby the smoke generated in them is discharged into a central area ("dimluk") which further warms the rooms to some extent ("heat recovery") and protects the wooden elements of the physical structure of the building,

6. The spatial concept of the building allows it to be used as a single and two-family house (flexibility of architecture).

\section{References}

1. Hadrović A. Defining Architecrural Space on the Model of the Oriental Style City House in Bosnia and Herzegovina, Serbia, Montenegro, Kosovo, and Macedonia. North Charleston, SC, USA: Booksurge LLC; 2007.

2. Hadrović A. Bioclimatic Architecture, Searching for a Path to Heaven. North Charleston, SC, USA: Booksurge LLC; 2008.

3. Hadrović A. Water and man in autoshthonous symbiosis in Bosnia and Herzegovina. Sarajevo: Avicena; 2014.

4. Hadrović A. Bosanska kuća ćardaklija, Sarajevo. Sarajevo: Arhitektonski fakultet u Sarajevu; 2017. 